Article

\title{
Building Relationships with Customer 4.0 in the Era of Marketing 4.0: The Case Study of Innovative Enterprises in Poland
}

\author{
Wioletta Wereda *(D) and Jacek Woźniak (D) \\ Institute of Organization and Management, Military University of Technology in Warsaw, 01-476 Warszawa, \\ Poland; jacekj.wozniak@wat.edu.pl \\ * Correspondence: weredawioletta@tlen.pl
}

Received: 6 May 2019; Accepted: 5 June 2019; Published: 7 June 2019

check for updates

\begin{abstract}
Background: Contemporary enterprises are putting more and more emphasis on shaping lasting and effective relationships with clients. This is not an easy task, especially in the conditions of Marketing 4.0, which imposes on enterprises the need to holistically consider the needs as well as the skills and inventiveness of customers. It can be assumed that Clients 4.0 require both changes in the scope of business processes and shaping communication with their environment. That is why it is important today to skillfully and correctly determine the complexity of communication with Clients 4.0 , as well as to determine the importance of communication with clients for the development of enterprises-especially those operating in innovative industries. (2) Methods: Empirical research was carried out on a sample of 100 innovative enterprises listed on the NewConnect market in Poland. The respondents were managers at various levels. Two indicators were constructed based on these assessments: Customer Relationships Importance Index (CRII) and Customer Communication Complexity Index (CCCI). (3) Results: It was determined that the complexity of communication of innovative enterprises with customers is at a high level. What is more, the importance of relationships with Customers 4.0 for the development of innovative enterprises is at a high level. It was also indicated that there is no correlation between the level of complexity of relationships with Customers 4.0 and the importance of these relationships for the development of innovative enterprises. (4) Conclusions: Based on the survey, it can be assumed that the relations with Clients 4.0 have the greatest share in shaping the development of innovative enterprises in the areas of minimizing the number of complaints, financial liquidity and efficiency of core business processes. It is also important that, in shaping the complexity of communication with Clients 4.0, enterprises mainly consider traditional phone calls and email account.
\end{abstract}

Keywords: Customer 4.0; Marketing 4.0; Industry 4.0; NewConnect market; building relationships; innovative enterprises; complexity of communication; importance of relationships

\section{Introduction}

According to various modern marketing concepts, each company should put a direct emphasis on the personal relationships between the client and the organization (Isoraite 2016; Dimitrov 2016). They should take the form of personalized relational communication, which is commonly referred to as a relationship based on mutual dialogue and trust between the participants of communication. In this approach, communication acts as a commitment that connects exchange partners and creates lasting relationships between them. Creating a desired customer relationship requires not only a customer-focused management system but a clear application of a specific marketing concept within the entire company (Yashin 1998). In the long-term perspective, the enterprise must take and use all available means to build ties of appropriate character in a specific concept, currently in Marketing 4.0. 
In the literature, "relationship" is defined as an interrelation, relationship or connection originated between entities of a given type appearing on the market. Kotler stated that relations should be long-term, trustworthy and built on the basis of mutual benefits for entities participating in it (Kotler 1997). The relations between the company and the customer have an interactive nature; moreover, in the perspective of the digital era, they have a more social character. This means that they are related to mutual interaction and co-creation. The customer interested in the offer has their own expectations towards the seller, while the seller directly affects the client in order to realize his/her expectations through various communication channels (Weitz 1981).

The division and types of relationships depend on many different factors. They correspond to the nature of a given area and functions aimed at the enterprise's goals. Considering the innumerable aspects and areas of the organization's operation, the number of relationships used in the market is really indefinable. Moreover, the number of new relationships and connections with various groups of stakeholders is constantly growing (Verm and Nellikar 2018). It is possible to distinguish between external relations with various entities of the environment (external stakeholders) as well as internal relations-including employees and structures within the enterprise. All criteria for distinguishing these relationships relate primarily to the entities themselves, their forms of communication, the type of marketing strategies and many other factors.

A contemporary client is a customer based on the Internet and actively working online, who is socially involved in a new digital reality, which is why his/her requirements are growing (Saura et al. 2019). On the one hand, new technologies give him/her great satisfaction and excitement, and on the other hand, give rise to anxiety and fear as to the automation of communication in the buyer-enterprise relationship.

The main objective of the study was to show how innovative enterprises operating on the NewConnect market implement communication processes with clients (referred to as Clients 4.0). The research problem was taken as follows: At what level is the complexity of communication processes with Clients 4.0 in innovative enterprises operating in Poland (on the NewConnect market), and what is the direction and strength of dependence between the complexity of communication processes (in the aspect of shaping relationships) of enterprises with clients and the impact of these relationships on the development of enterprises?

The article consists of three main parts. The first concerns the literature review related to the identification of Customer 4.0 attributes and ways of shaping the communication with Customer 4.0 by innovative enterprises. The next part is the conceptualization of the study, the determination of the scope of the empirical study and the specification of the research sample. An important element of this part of the article is the methodology of Customer Relationships Importance Index (CRII) and Customer Communication Complexity Index (CCCI) indicators that were used to verify hypotheses. In the third part, the results of the empirical study and the specification of applications are analyzed.

\section{Literature Review}

\subsection{Marketing 4.0 and Client Relations Building}

Traditional marketing begins its activities from segmentation, targeting and allocation of funds through their more effective positioning. These elements help marketers to service many markets and segments as well create a diverse offer. However, segmentation and targeting are a manifestation of vertical relations between the company, its brand and clients. Often, marketers define variables and the involvement of clients is limited to conducting marketing research on them to create a specific promotional campaign for them. The changing world of business, new technologies and the development of the Internet in every area of life in recent decades have led to the fact that, in the present digital age, Marketing 4.0 combines online and offline interactions between clients and enterprises.

It is in a world where the customer is getting more and more into the online reality that the offline approach can be a strong element distinguishing the organization. Marketing 4.0 is designed to 
combine the communication style and the core of the goal. Enterprises must be more and more flexible and adapt their own structures and brands faster to changing social, market and technological trends, as well as maintaining the true nature of their company. Authenticity is the largest capital in the situation of ever-increasing transparency of information on the web (Kotler et al. 2017). In new marketing concepts, particular attention is paid to the creation of lasting relationships with the client, with greater emphasis on his deeper knowledge, ensuring satisfaction and creating a brand advocate. Marketing 4.0 is a deepened and expanded marketing of previous generations, more human-centric, which deals with every aspect of the consumer's journey in real and electronic life. The role of marketers is to guide customers on their journey from the stage of awakening the awareness of a product or service to the final stop, which is intercession, that is, propagation of knowledge about the product by these consumers (Gregor 2002). The characteristics of individual generations of modern marketing are presented in Table 1.

Table 1. Comparison of modern generations of Marketing 1.0, 2.0, 3.0 and 4.0.

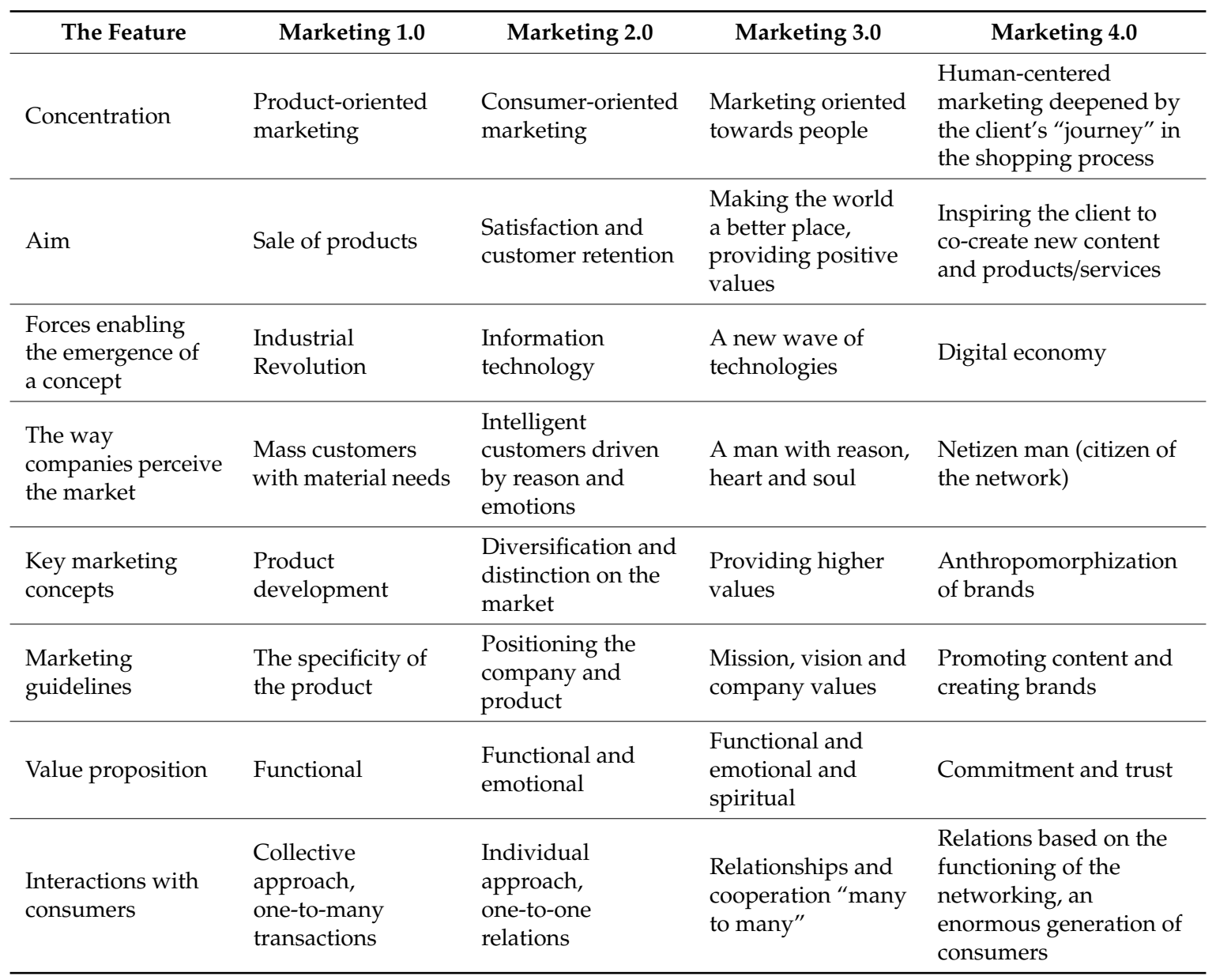

Source: (Kotler et al. 2010, 2017).

The future of marketing will be shaped on an ongoing basis through everyday events of economic and social life. Over the past few decades, companies around the world have experienced various recessions but also successes. Unfortunately, most customers around the world accepted a lifestyle that was based on the "buy now, pay later" principle, but, as a result of credit regulations and more stringent bank policy towards the customer from the beginning of the economic crisis around the world, spending was more limited by customers. This means that marketing specialists have to work harder and harder to attract consumers to new and existing products and services. It should be noted that there is an evolution in marketing for next generations; Marketing 1.0 or 2.0 are still applicable, because 
the market segmentation, target group selection, positioning, $4 \mathrm{P}$, branding and building relationships with the customer are still important. However, various changes in the business environment, such as the recession, climate issues, new social media, greater power and consumer influence, next-generation technology and globalization will be continuing factors that stimulate the gradual transformation of marketing practices (Kotler et al. 2010).

Globalization now creates equal opportunities for many societies and economies. Contemporary competitiveness of enterprises will not depend on their size, the country they come from or their advantages in the past. Companies will be gaining leadership if they can establish relationships with communities of customers and other partners to co-create products or services. The flow of information that has been vertical becomes horizontal, which is why a modern customer can not only receive data from an enterprise, but should be perceived as equal to the brand and as a friend of the enterprise. The concept of trust in the company; true character, honestly presented values by organizations, creating credibility are the elements that can build a solid foundation for forming relations on the plane: client-enterprise. According to the literature, there are many aspects of building relations with customers (Table 2).

Table 2. Selected definitions of "building relations with clients" due to literature.

\begin{tabular}{|c|c|c|c|}
\hline Author & Paper Classification & $\begin{array}{c}\text { Main Characteristic of the Process } \\
\text { and Description }\end{array}$ & $\begin{array}{l}\text { Reference to the } \\
\text { Communication Process }\end{array}$ \\
\hline Singh (2003) & Research paper & $\begin{array}{l}\text { Building relations with clients is to provide } \\
\text { easy and quick access to information } \\
\text { products and services without } \\
\text { compromising service quality while } \\
\text { maintaining customer. }\end{array}$ & YES \\
\hline $\begin{array}{l}\text { Claycomb and } \\
\text { Martin (2001) }\end{array}$ & Research paper & $\begin{array}{l}\text { "Customer relationship-building" means } \\
\text { different things to different people and that } \\
\text { practices to build such relationships vary } \\
\text { considerably. The four rated as top } \\
\text { priorities were found in the research: } \\
\text { encouraging customers to think of the firm } \\
\text { first when considering a purchase; } \\
\text { providing better service; encouraging } \\
\text { customers to speak favorably about the } \\
\text { firm; and encouraging customers to trust } \\
\text { the firm. }\end{array}$ & YES \\
\hline $\begin{array}{l}\text { Hastings and } \\
\text { Perry (2000) }\end{array}$ & Research paper & $\begin{array}{l}\text { Services firms should adopt a relationship } \\
\text { marketing approach while goods firms } \\
\text { might use a transactional approach. } \\
\text { Building relations with clients is crucial to } \\
\text { initiating and maintaining an } \\
\text { export strategy. }\end{array}$ & YES \\
\hline $\begin{array}{l}\text { Ayios and Harris } \\
\qquad(2005)\end{array}$ & Research paper & $\begin{array}{l}\text { The customer perception is of an } \\
\text { organization that is concerned with } \\
\text { building relationships based on competence } \\
\text { or empathy to meet individual } \\
\text { needs-features which stand out clearly in } \\
\text { an industry sector often associated with } \\
\text { standardized services, "sweatshop" } \\
\text { working conditions and control-based } \\
\text { management practices focused on a purely } \\
\text { economic rationale. }\end{array}$ & YES \\
\hline
\end{tabular}


Table 2. Cont

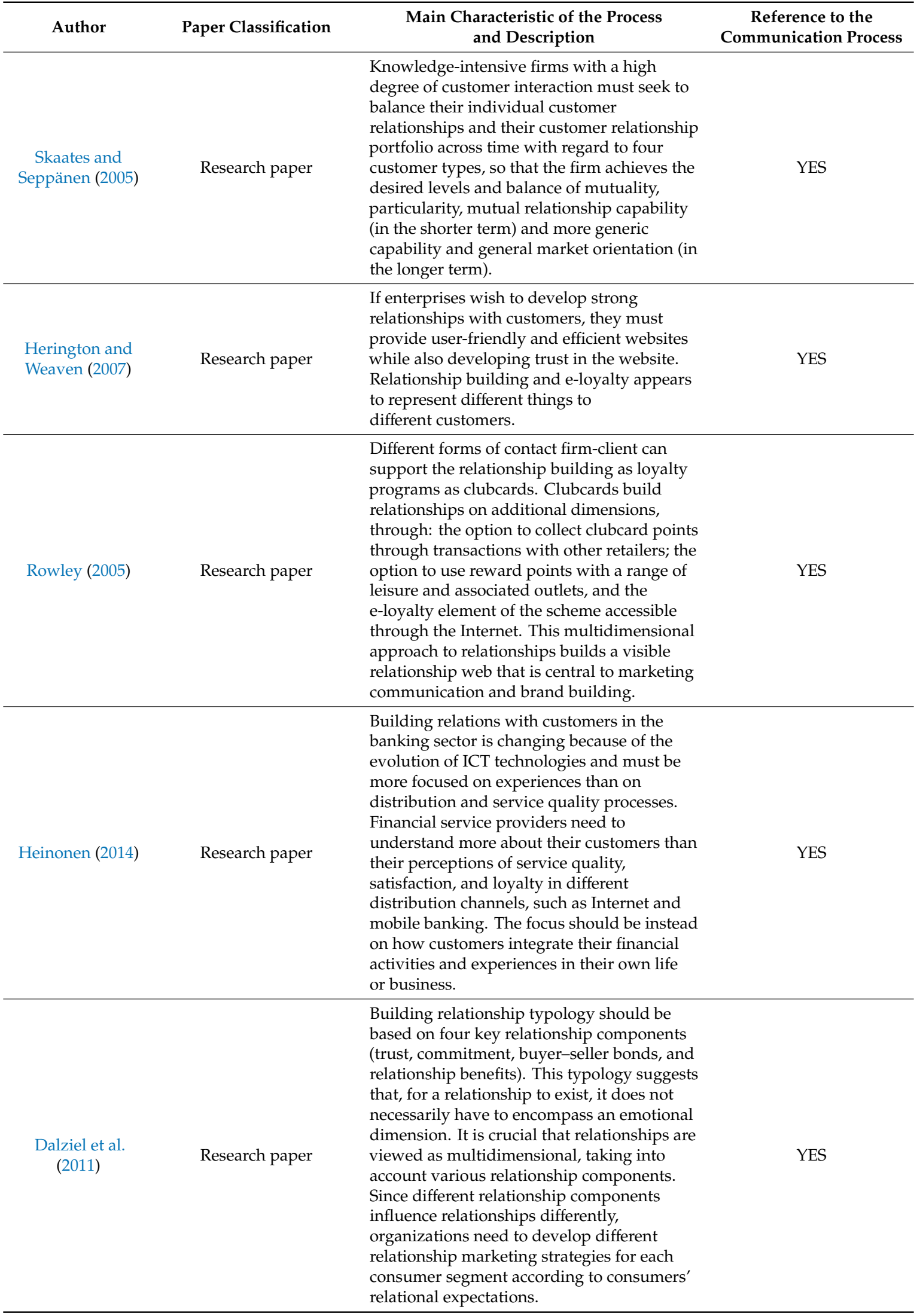


According to many research, the most important aspect is the fact that the enterprise is able to build various types of relationships with the customer. Depending on the aspect of the relationship and the form of business transactions or behavior, relations can generally be divided into (Wereda and Zaskorski 2018):

1. Reactive relationships consist of the fact that the enterprise sells products to customers and encourages them to make contact in the case of any doubts or problems.

2. Proactive relations boil down to the fact that the company periodically contacts clients to inform them about new products in the offer or to provide suggestions for using the product. Currently, such materials are sent mainly by e-mail (e.g., in the form of newsletters or a call center).

3. Responsible relationships depend on the fact that the enterprise contacts the customer after the purchase to check whether the product meets the expectations of the consumer. The company also tries to systematically learn about the possible improvement of the product and determine the reasons for possible dissatisfaction with the purchase. In responsible relations, communication on the company-company line takes the form of a dialogue. Such feedback allows the company to best match the offer to the customer's needs (Dejnaka 2013).

4. Relations based on trust consist of creating trust between the client and the company, because this is the foundation of the mutual commitment of the parties and striving to maintain the continuity of the relationship. The occurrence of trust both within the organization and in relations with the environment is not obvious, especially in the conditions of uncertainty, crisis or the high value of the object of relational exchange (Jończyk 2010).

5. Customer relations in the network consist of consciously building positive relationships with the consumer online, from the very beginning of the enterprise's existence on the website, also through the social media platform or creating blogs or company portals.

6. Relations based on intercession rely on creating in the minds of customers the sincere and honest image of a service/product provider so that conversations about the company with other clients in the social circles, both "face to face" and online, influence the purchasing behavior of other people. Such social contacts have more influence on the choice of brand or loyalty to the company than false promises or advertising tricks of big marketing companies (Kotler et al. 2017).

Generally, it should be noted that building customer relationships is critical to the existence of a product, brand or enterprise on the market. Depending on the power, influence and possibilities of the development there are many types of relationships presented in Table 3.

\subsection{Attributes and Characteristics of Client's Communication and Relational Behaviors 4.0}

According to many studies, the best-known attributes of clients are connected with their generation. In the literature, there is a division into four groups of generations of people functioning in contemporary organizations as employees and customers (Marston 2005):

- Mature

- $\quad$ Baby boomers

- Generation X

- Generation Y

Due to contemporary researchers (Kozłowski 2012), technological progress and IT development have made that representatives of the generation named $\mathrm{Z}$ and Alpha have appeared on the labor as well customer market, representing new reality, including that in the virtual and electronic dimensions (Figure 1). Generally, a massive impact of the digital economy is that customers are constantly connected; anytime, anywhere, anyhow. Each client has a continual ability to interact with friends, family, peers, teams, suppliers or other customers during choosing, selecting or purchasing a product or service. What is more, this is the base of Customer 4.0, a fourth generation of e-commerce, led by younger and highly influential generations, where the customer is truly in control (Freeman 2017). 
Table 3. Classification of business relationships with clients due to selected criteria.

\begin{tabular}{|c|c|}
\hline Criterion & Type of Relationship \\
\hline Power on the market & $\begin{array}{l}\text { Relations dominated by the enterprise, relations dominated by } \\
\text { clients, relations of equal partners }\end{array}$ \\
\hline The degree of ordering of contacts & $\begin{array}{l}\text { Ordered relations (in the form of long-term commercial contracts), } \\
\text { unstructured relations (orders are carried out continuously, but } \\
\text { without the conclusion of commercial contracts), sporadic } \\
\text { relationships (depending on the order), fuzzy relations (depending } \\
\text { on market factors) }\end{array}$ \\
\hline $\begin{array}{l}\text { The degree of stability and mutual } \\
\text { loyalty in relation }\end{array}$ & $\begin{array}{l}\text { Stable relations, unstable relations, relations of intercession, relations } \\
\text { of advocate loyalty }\end{array}$ \\
\hline Number of contacts & Frequent relations, rare relationships \\
\hline $\begin{array}{l}\text { Geographical scope of the } \\
\text { company's operation on the } \\
\text { market }\end{array}$ & $\begin{array}{l}\text { Relationships with local clients, customer relations within a regional } \\
\text { range, customer relations at the national level, customer relations at } \\
\text { an international level, customer relations in a global range }\end{array}$ \\
\hline Long-term relationships & $\begin{array}{l}\text { Ad hoc relationships created without loyalty, only for a limited time } \\
\text { relationships created on the basis of long-term contracts }\end{array}$ \\
\hline Formalization of relationships & $\begin{array}{l}\text { Formal relations in the form of bilateral agreements, informal } \\
\text { relations on the basis of an oral contract }\end{array}$ \\
\hline $\begin{array}{l}\text { The strength of the company's } \\
\text { connections with the customer }\end{array}$ & Strong relationships, weak relationships \\
\hline $\begin{array}{l}\text { Place of transaction and } \\
\text { relationship }\end{array}$ & $\begin{array}{l}\text { Off-line relations (making purchases and building relationships at } \\
\text { stationary points), on-line relations (making purchases and building } \\
\text { relationships only in cyberspace) }\end{array}$ \\
\hline $\begin{array}{l}\text { Product innovation and } \\
\text { relationship service }\end{array}$ & $\begin{array}{l}\text { Quick innovation relations (focused on quick creation by companies } \\
\text { of innovative products and offering customers before they are } \\
\text { released on the market), slow innovation relationships (focused on } \\
\text { creating innovative products by companies and offering customers } \\
\text { after they are released on the market), open innovation relations } \\
\text { (clients in the course of long-term cooperation and purchases in the } \\
\text { enterprise become prosumers and also co-design market novelties) }\end{array}$ \\
\hline $\begin{array}{l}\text { Location in the value } \\
\text { chain network }\end{array}$ & Vertical relations, horizontal relations, mixed relations \\
\hline
\end{tabular}

Source: (Cygler 2002; Todeva 2006; Czakon 2012; Witek-Hajduk et al. 2016; Wereda and Zaskorski 2018).

To specify contemporary Customer 4.0, it is necessary to present the characteristic of former generations of client:

1. Customer 1.0 (before the 1950s): Customers benefited from the production or delivery capability of the business. They had little choice, and mostly bought products that were available on the market at that time.

2. Customer 2.0 (1950-1990): The principles of Customer 1.0 were still alive, supported by the development of consumerism and traditional marketing. The concepts of brand first emerge, and customer demand for products and services were strongly driven by marketing.

3. Customer 3.0 (1990-2015): The principles of Customer 1.0 and 2.0 continue, but expanded by the explosion of globalization and the Internet. Customer retention and loyalty are key features, and the focus of competitive action is on delivering the best possible customer experience (Freeman 2017). 


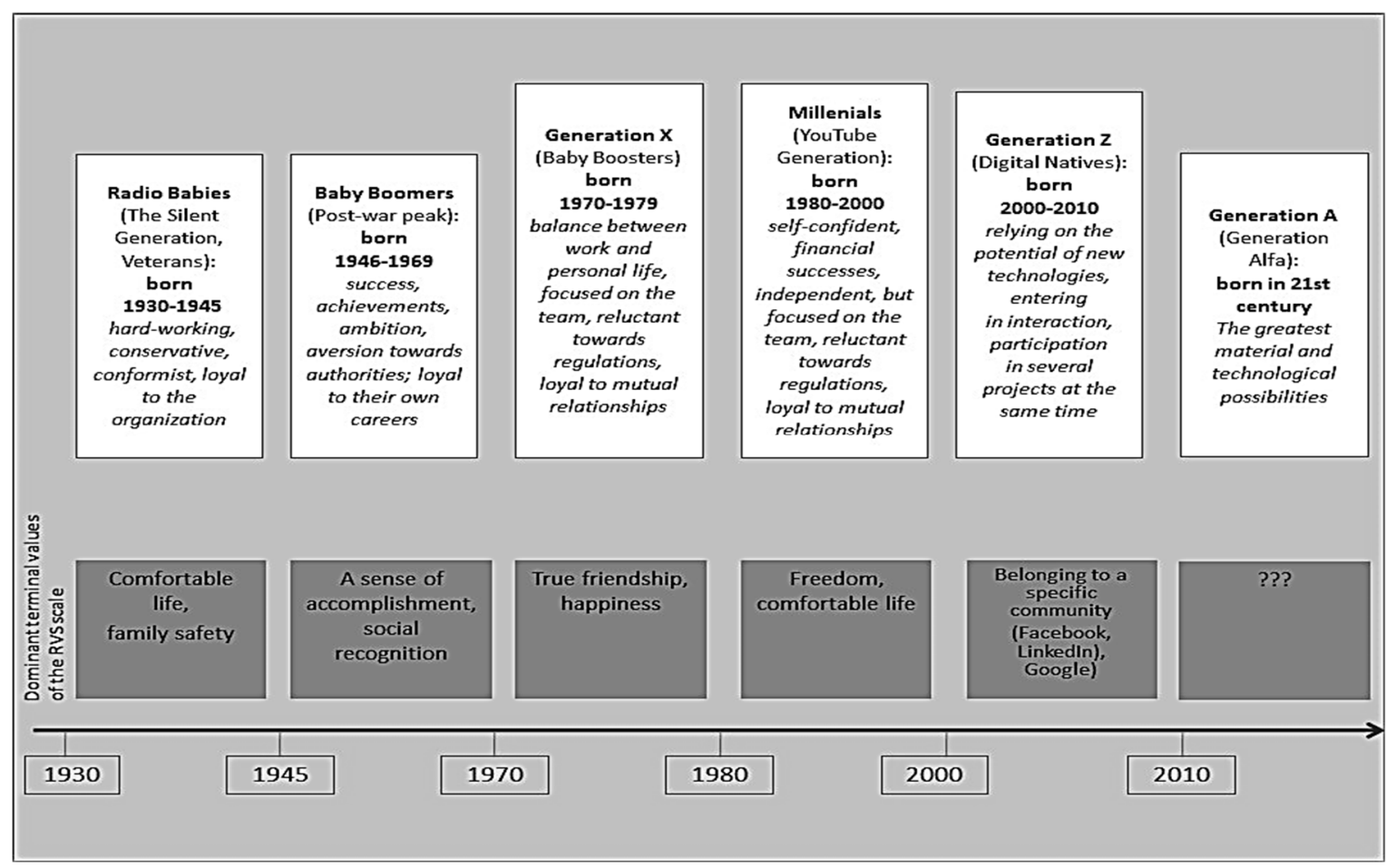

Figure 1. The evolution of generations of people and their values through decades. Source: (Robbins 2008; Wereda 2018).

According to many researchers Customer $4.0(2015+)$ is a person whose principles (based on experiences of Customers 1.0, 2.0 and 3.0) continue to evolve, but are now complicated by vast choices, online platforms and has emerged as a new type of customer: One whose personal goals outweigh persuasive marketing. One who seeks to influence and be influenced by other customers. One who employs very new ways of working and thinking; who has high expectation that a provider will change the way they deliver to fit with their needs. Where the customer's journey is their unique journey, where businesses play a part in enabling them to achieve their goals. This customer is a netizen, very demanding, highly informed by electronic devices and looking for developing, competitive and innovative approaches to different challenges on various spheres such as banking, professional services, automotive and IT services, healthcare, education, utilities, (most aspects of) manufacturing and construction, etc. (Freeman 2017; Kotler et al. 2017). What is more, it should be noted that there are sensible differences in customer behavior depending on their interest level. When customers are interested in an item, they observe the item for a longer duration of time and have a more balanced speaking style (Kim et al. 2009). It is also important to create for the contemporary customer a quick service with high quality resources and products without wasting time on extra activities (Stefanini et al. 2018). Generally, Customer 4.0 in his/her purchasing process is trying to find a market with wide choice of providers. In clear examples of market disruption, long-term traditional businesses have radically changed or are being replaced by new brands, the range and volume of $\mathrm{C} 2 \mathrm{C}$ (Customer to Customer) communication dominates for example social media. The main features characteristic of Customer 4.0 are presented in Table 4 . 
Table 4. Characteristics of Customer 4.0.

\begin{tabular}{|c|c|}
\hline Factor & Traits of the Customer 4.0 \\
\hline Personal factor & $\begin{array}{l}\text { 1. He/she wants to be treated with respect and individually. } \\
\text { 2. He/she is demanding and at the same time grumpy. } \\
\text { 3. Most customers are undecided but want to have a large } \\
\text { 4. Looks for individual benefits with every purchase. } \\
\text { 5. He/she is impatient during the purchase. } \\
\text { 6. He/she often quickly becomes aggressive. } \\
\text { 7. Has a lot of knowledge about products/services. }\end{array}$ \\
\hline Market factor & $\begin{array}{l}\text { 1. He/she rarely buys the same product/service because he/she } \\
\text { compares the prices of the competition. } \\
\text { 2. Looking for discounts and sales opportunities. } \\
\text { 3. Replaces suppliers and brands of products quite quickly, if } \\
\text { they find more favorable prices. } \\
\text { 4. Draws attention to the quality of products/services. } \\
\text { 5. He/she does not buy rashly and compares products. }\end{array}$ \\
\hline Organizational and IT factor & $\begin{array}{l}\text { 1. He/she expects from the seller a high personal culture } \\
\text { and respect. } \\
\text { 2. Expects solid and honest advice and opinions about the } \\
\text { product service. } \\
\text { Has a lot of sales experience and analyzes everything } \\
\text { before buying. } \\
\text { 5. Hasers electronic to stationary shopping. }\end{array}$ \\
\hline Social factor & $\begin{array}{l}\text { 1. He/she is claiming and knows his purchase possibilities (he is a } \\
\text { 2. Habal client). } \\
\text { position of a person "stupidly wise". } \\
\text { 3. Has limited confidence in traders. } \\
\text { 4. He/she is not loyal to products/services and brands } \\
\text { of companies. }\end{array}$ \\
\hline
\end{tabular}

Source: (Wereda 2018; Freeman 2017; Kotler et al. 2017).

In summary, the Customer 4.0 principles in the purchasing sphere are:

- Be purposeful: The main purpose in the mind of the customers is to be unique, individual, have the best quality of goods and services, positive experiences on the market and have opportunities to buy anytime, anywhere and successfully online or offline.

- Be authentic: Be the best and real to others and be treated with high respect online and offline.

- Be agile and responsive: Continuous learning, reviewing and improving professional and personal by positive experiences on the market.

- Be valued: Continually thinking of different types of value and evaluation of the power of value propositions from enterprises; genuinely believing in brands and enterprises' offers in case of trust and relying on known businesses because of the value they received in the past.

- Be engaged: Advocate customers are engaged in enterprises' marketing by being active in social groups and portals as well in the creation of fun clubs of brands.

It can therefore be concluded that, in the Marketing 4.0 concept, the consumer becomes an entity that wants to cooperate because of benefits, moral satisfaction, and their own commitment. However, 
it should be noted that all consumer attitudes are present in contemporary markets and specific groups evolve in the long term under the influence of globalization, information, social changes, etc. (Figure 2).
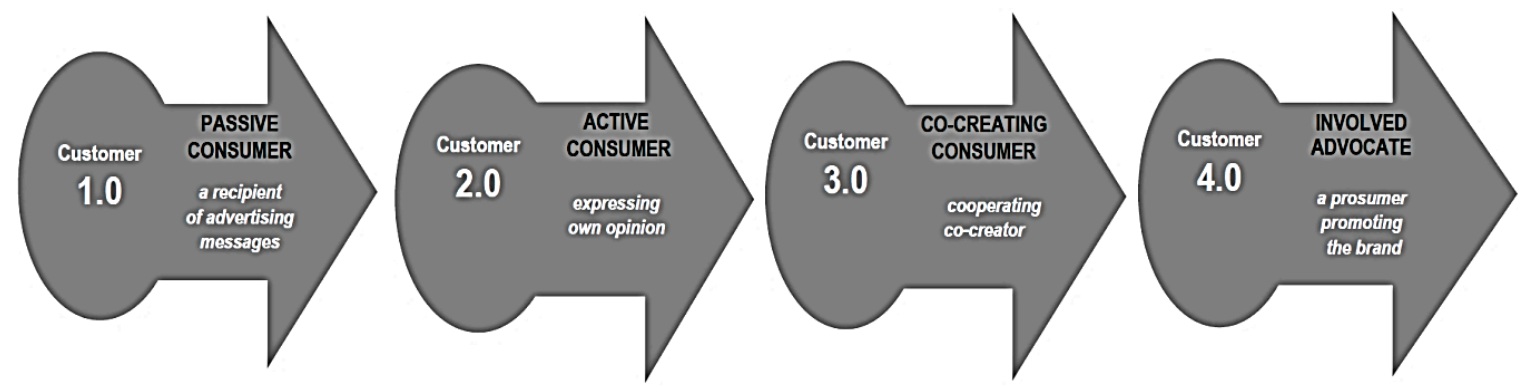

Figure 2. Changes in customer attitudes in relation to his/her market activity trough decades. Source: Own work based on (Nowacki 2014).

In connection with the above illustration, an important element is the form of communication and the client's path in the purchasing process. In the modern market, every communication channel has its value for the customer who wants to be aware of what he/she buys, the offer is attractive to him/her, has the ability to easily contact and ask questions to sellers and is able to quickly purchase, and if he/she is satisfied then they will advocate the company and its brand. Customer 4.0 activity, in the sphere of both online and offline, must give him/her the possibility of easy contact through various intermediary media, but also in person. The client uses the basic communication channels as well as the contact center, helpline and especially social media/social networks (Antonacci et al. 2017; Wasserman and Faust 1994). An important element is the linking of sales and communication channels for Customer 4.0, because it is he/she who has to make a choice, act and become an involved party in a commercial transaction (Kotler et al. 2017; Lopes 2019).

What is more, the exchange information within the network, growing self-awareness (developing of freelancing) and buyers' expectations, for example bigger demand for transparency, personalization of products and brands created with their cooperation, building partner relationships, moving away from product ownership towards product access and utility, sharing services, more convenience and positive experience than ownership, using and buying products that are aware of their behavior and needs (smart products and services), etc. (Tarabasz 2013; Lopes 2019).

It should be added that communication processes with Customer 4.0 are both the basis for the implementation of traditional forms of communication, and define the conditions and rules for the use of specific ICTs (Ziółkowska and Karbownik 2018). What is more, the processes of communication in innovative enterprises are associated with the identification of specific opportunities (in the form of organizational and business benefits) and threats (in the form of potential material/financial/intellectual losses) (Hollman et al. 2018; Dahiya and Gayatri 2018; Bergman et al. 2016). Information and communication technologies, through improving communication mechanisms between process providers, are able to determine the creation of added value for the firm's clients (Wereda 2012). Nowadays, the basic directions of development of ICT technologies are (Lehrer et al. 2018; Caruso 2018; Muzellec and O'Raghallaigh 2018; Calitz and Zietsman 2018; Sajić et al. 2018; Grable and Lyons 2018; Müller et al. 2018; Grover et al. 2018; Kitchens et al. 2018): Internet of Things, Cloud Computing, Big-Data systems, data exploration systems, mobile technologies, and Wi-Fi as well as Web 2.0 technologies. It should be emphasized that specific ICTs support in communication process of the enterprise with its clients can create strong and transparent relations.

\section{Conceptual Framework and Research Questions}

Customers and their behaviors today are of great importance for the development of enterprises. This is particularly important in innovative industries, where creating and providing value to clients (principals) cannot, in principle, take place without their active participation in innovative processes. 
Therefore, prosumption (its scope and complexity) determines the degree of meeting the needs and requirements of customers. It is also important that the involvement of clients in the operation of enterprises allows for flexible consideration of their limitations (e.g., financial, information, human, etc.). Therefore, processes aimed at increasing the level of customer satisfaction can be improved-by adjusting the company's operations to the specifics of the client. This phenomenon is particularly important in the case of so-called Customers 4.0 who are deemed to expect the highest value from the company (the product or service provider), want to decide how their order is implemented (what features the product will have), look for unique values (impossible to imitate), are impatient, mobile and they do not know geographical boundaries (Manufacturers 2018; Fastener 2017; Contify Automotive News 2018).

It can therefore be assumed that the subject matter of the study concerns shaping customer relationships (referred to as Clients 4.0), mainly through the implementation of communication processes with them (in a traditional or modern way). An important issue in the article is the linking of the complexity of the communication of enterprises with Customers 4.0 and the impact of these clients on the development of enterprises.

The research questions were:

- What communication channels with clients are currently used by innovative enterprises and what channels of communication are important in the opinions of Customers 4.0? According to the research in (Samson et al. 2014; Abedi 2019; Amendola et al. 2018; Lee and Park 2019; Rostami et al. 2016), communication with customers should take place mainly by using ICT and the complexity and the number of used technologies may positively have the influence on the quality of communication with clients, also with Customer 4.0.

- What impact does the communication with Customers 4.0 have on the development of contemporary, innovative enterprises? Can Customers 4.0, their needs and requirements stimulate the development of enterprises? According to the research in (Syreyshchikova et al. 2019; Engelbrecht et al. 2019; Van den Berg et al. 2019), ICTs used in the communication process of enterprises with clients can support the development of enterprises in various aspects, e.g., decision processes and knowledge management, production or the development and implementation of the corporate architecture.

- What is the direction and strength of the relationship between the complexity of communication of innovative enterprises with Customers 4.0 and the importance of this communication for the development of enterprises? According to the research in (Matinaro et al. 2019; Dombrowski et al. 2019), the more complex and multifaceted communication with clients is, the greater may be the impact of used ICT technologies and customer relationships on the enterprise development and shaping its excellence, in terms of both business and structure.

Three hypotheses (statistically significant at 0.01) were put forward to achieve the goal of the study:

Hypothesis 1 (H1). The complexity of communication of innovative enterprises with customers is at a high level.

Hypothesis $2 \mathbf{( H 2 ) . ~ T h e ~ i m p o r t a n c e ~ o f ~ r e l a t i o n s h i p s ~ w i t h ~ C u s t o m e r s ~} 4.0$ for the development of innovative enterprises is at a big level.

Hypothesis 3 (H3). The higher is the level of complexity of relationships with Customers 4.0, the greater is the importance of these relationships for the development of innovative enterprises. 


\section{Methodology}

\subsection{Research Sample}

The subjective scope of the research is innovative enterprises operating on the NewConnect market in Poland. The study included 100 enterprises (25.3\% of entities from the population-a population of 396 companies from Poland). The subject structure of the activities of the surveyed entities is included in Table 5.

Table 5. Leading business profiles of enterprises $(\mathrm{N}=100)$.

\begin{tabular}{ccc}
\hline Leading Business Profile & Number of Enterprises & Percent of Enterprises \\
\hline Trade & 16 & 16 \\
Financial services & 15 & 15 \\
Building and construction & 8 & 8 \\
New technologies & 8 & 8 \\
E-commerce & 8 & 8 \\
Media & 7 & 7 \\
Computer science & 7 & 7 \\
Eco-energy & 5 & 5 \\
Eco-production & 5 & 5 \\
Production & 5 & 5 \\
Health protection & 5 & 5 \\
Telecommunications & 3 & 3 \\
Leisure and tourism & 3 & 3 \\
Real estate & 3 & 3 \\
Recycling & 2 & 2 \\
\hline
\end{tabular}

The study used a systematic random selection (taking into account the criterion of the leading activity profile indicated for the NewConnect market) in the layers (the layers correspond to the size of the enterprise). Respondents were managers or managers (of the highest or middle level) responsible for the area of relations with the environment or innovations, or operational employees (the lowest level) employed in enterprises listed on the NewConnect market. One respondent from each company was qualified for the study. The structure of the research sample-considering different criteria-is described in detail in Table 6. The structure of enterprises included in Tables 5 and 6 reflects the general structure of the innovative enterprises listed on the NewConnect market, but does not reflect the structure of the Polish economy. The empirical study was conducted in the period June-July 2018 and covered the entire country (16 provinces in Poland). The largest number of surveyed enterprises was based in central Poland (Figure 3).

\subsection{Research Method}

The survey tool was a CATI (Computer-Assisted Telephone Interviewing) questionnaire, in which respondents on a five-point scale assessed the level of impact of building long-term, good customer relationships on the company's operations and the degree of application of certain means of communicating with clients. The results of the $k$ th question $(k=1 \ldots 15)$ given by the $n$th respondent $(n=1 \ldots 100)$ were subjected to statistical analysis-factor analysis. The calculations were carried out using the IBM SPSS Statistics 24 software (PS IMAGO 4.0). The study also employed a method of critically analyzing literature, methods of analysis, synthesis and induction. 
Table 6. Criteria for description of the research sample $(\mathrm{N}=100)$.

\begin{tabular}{|c|c|c|c|}
\hline \multicolumn{2}{|c|}{ Criteria } & \multirow{2}{*}{$\begin{array}{c}\text { Number of Enterprises } \\
40\end{array}$} & \multirow{2}{*}{$\begin{array}{c}\text { Percent of Enterprises } \\
40\end{array}$} \\
\hline & Small & & \\
\hline Size of enterprise & Medium & 31 & 31 \\
\hline & Big & 29 & 29 \\
\hline \multirow{5}{*}{$\begin{array}{l}\text { Scale of enterprise's } \\
\text { operation }\end{array}$} & Local & 6 & 6 \\
\hline & Regional & 1 & 1 \\
\hline & Domestic & 24 & 24 \\
\hline & European & 38 & 38 \\
\hline & International & 31 & 31 \\
\hline \multirow{6}{*}{$\begin{array}{l}\text { Revenue for the } \\
\text { year (net) }\end{array}$} & 0-10 mln PLN & 37 & 37 \\
\hline & 10-20 mln PLN & 17 & 17 \\
\hline & 20-30 mln PLN & 9 & 9 \\
\hline & 30-50 mln PLN & 8 & 8 \\
\hline & 50-100 mln PLN & 11 & 11 \\
\hline & More than $100 \mathrm{mln}$ PLN & 18 & 18 \\
\hline \multirow{3}{*}{$\begin{array}{l}\text { Respondent's position } \\
\text { in enterprise }\end{array}$} & $\begin{array}{l}\text { The highest level of } \\
\text { management }\end{array}$ & 52 & 52 \\
\hline & $\begin{array}{c}\text { The intermediate level of } \\
\text { management }\end{array}$ & 23 & 23 \\
\hline & $\begin{array}{c}\text { The lowest level of } \\
\text { management }\end{array}$ & 25 & 25 \\
\hline
\end{tabular}

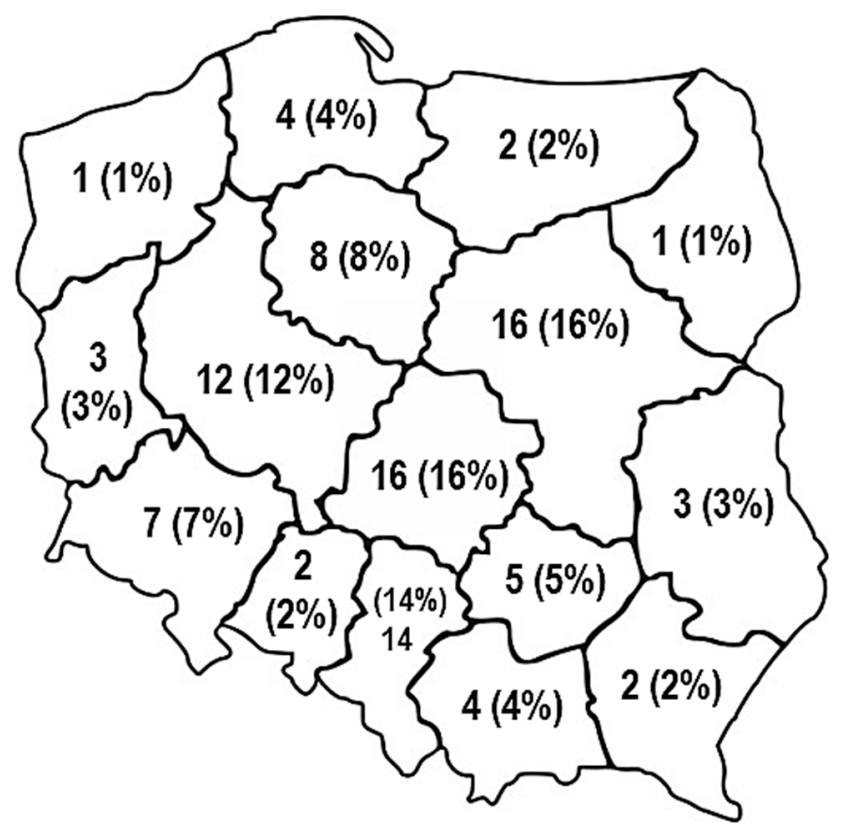

Figure 3. Number and percent share of surveyed enterprises in voivodships in Poland.

To verify Hypotheses 1 and 2, two composite indexes were constructed:

- Customer Communication Complexity Index (CCCI); and

- Customer Relationships Importance Index (CRII).

To answer the above problem, the methodology of constructing both indicators, referring to specific partial factors (Tables 8 and 15), will be presented. These factors (as specific generalizations of various activities and processes) were specified based on the analysis of the current literature on Customer Attributes 4.0, shaping the relationships with this customer class, as well as the impact of modern clients on the operations of enterprises operating in industry 4.0 (Green 2018; Dukić et al. 2018; 
Saniuk and Saniuk 2018; Gunasekaran et al. 2019; Bowers and Pickerel 2019; Mourtzisa et al. 2019; Lorenz et al. 2018).

The composite ratios of CCCI and CRII were used in the study because (Nardo et al. 2005):

- they give a chance to include a relatively large number of partial factors and group them into coherent components;

- they enable conducting a holistic analysis; and

- they provide the basis for quantification and evaluation of the phenomena studied.

The factors included in the study (for the purposes of both CCCI and CRII) were to measure (on a five-point scale) the approach of enterprises to implement individual actions in communication with Customers 4.0 and the impact of customer relations on the company's operations. The value of " 1 " meant that the given activity (as part of communication) is very rarely implemented or the impact of customer relationships on the enterprise is at a very low level, and the value of " 5 " that the action is implemented very often or the impact of customer relations is very big. The reliability of the scale was analyzed using the Cronbach's alpha coefficient to verify the quality of the data.

\subsection{Construction of Indicators}

To increase the transparency of the conducted analyzes and give the structure to inference processes, individual indicators are described separately. The Customer Communication Complexity Index (CCCI) is the first developed. For a full list of the eight factors defining the means of communication between enterprises and clients, the Cronbach's alpha coefficient value was 0.557 (the first iteration). Taking into account methodological recommendations, the value obtained could not be considered sufficient. The analysis (in two subsequent iterations) indicated that there is the possibility of increasing the reliability and quality of the scale in the event of removing the second factor-traditional methods-in the form of paper documentation (second iteration-Cronbach's alpha at 0.557 ) and factor No. 3-traditional methods-in the form of direct conversations and team meetings (third iteration-Cronbach's alpha at 0.609). The third iteration showed that further exclusion of factors would not improve the quality of the mapping of the studied phenomenon of relationship sales maturity in the research tool. Finally, six factors were used to construct the CCCI index (Table 7), with a low Cronbach's alpha value of 0.636 (Table 8).

Table 7. Main factors of the complexity of communication with customers-Cronbach's alpha statistics.

\begin{tabular}{cccc}
\hline Factors & $\begin{array}{c}\text { Mean of Scale after } \\
\text { Deleting Factor }\end{array}$ & $\begin{array}{c}\text { Variance of Scale after } \\
\text { Deleting Factor }\end{array}$ & $\begin{array}{c}\text { Cronbach's Alpha after } \\
\text { Deleting Factor }\end{array}$ \\
\hline $\begin{array}{c}\text { f1-traditional forms of } \\
\text { promotion }\end{array}$ & 18.2200 & 20.093 & 0.599 \\
f4-phone (traditional \\
$\begin{array}{c}\text { phone calls) } \\
\text { f5-email account }\end{array}$ & 15.4200 & 22.266 & 0.636 \\
f6-corporate portals & 15.7600 & 19.417 & 0.617 \\
(personalized user accounts) & 16.7300 & 18.664 & 0.622 \\
f7- external instant & 16.5400 & 15.988 & 0.537 \\
messaging & 17.0300 & 14.716 & 0.512 \\
\hline
\end{tabular}

Table 8. Cronbach's alpha factor for factors of the complexity of communication with customers.

\begin{tabular}{cc}
\hline Cronbach's Alpha & Number of Factors \\
\hline 0.636 & 6 \\
\hline
\end{tabular}

A methodological recommendation developed by the OECD (2008) was used for the Customer Communication Complexity Index (CCCI). The methodology adopted included stages (Nardo et 
al. 2005): (1) determining the scope of measurement and the legitimacy of using the composite index; (2) selecting partial factors; (3) assessing the quality of empirical data; (4) assessing the relationship between partial factors; and (5) giving weights to partial factors and aggregating them to the composite index.

The results of the first three stages are included in Tables 7-9. In the assessment of the relationship between partial factors and their aggregation to the CCCI composite index, the factor analysis method was used (by means of the principal component analysis-PCA) (Hudrliková 2013). The Kaiser-Mayer-Olkin coefficient was used to verify the correctness of PCA application and Bartlett's sphericity test. The limit value of KMO coefficient is taken at the level of 0.5-0.7 (Williams et al. 2012). In the analyzed case, the KMO coefficient assumed the value 0.663 . Bartlett's sphericity test showed that the hypothesis of uncorrelated coefficients can be rejected-the test statistic is 81,814 with a significance level of less than 0.001. Further PCA analysis was justified and methodically correct (Table 10).

Table 9. Descriptive statistics for factors of the complexity of communication with customers.

\begin{tabular}{ccc}
\hline Factors & Mean & Standard Deviation \\
\hline f1—traditional forms of promotion & 1.7200 & 1.10170 \\
f4-phone (traditional phone calls) & 4.5200 & 0.87016 \\
f5—email account & 4.1800 & 1.35870 \\
f6-corporate portals (personalized user accounts) & 3.2100 & 1.51954 \\
f7—external instant messaging & 3.4000 & 1.60177 \\
f8—social networks & 2.9100 & 1.72969 \\
\hline
\end{tabular}

Table 10. KMO sample adequacy and Bartlett test.

\begin{tabular}{ccc}
\hline & & Statistics \\
\hline \multicolumn{2}{c}{ KMO sample adequacy } & 0.663 \\
\hline \multirow{3}{*}{ Bartlett test } & Approximate chi-square & 81.814 \\
& df & 15 \\
& Significance & 0.000 \\
\hline
\end{tabular}

In the further analysis, the method of distinguishing main component factors with Varimax rotation was applied. However, the selection of components was based on the Kaiser criterion. Factor analysis gave the basis for qualifying six factors to two components whose sum of squares after rotation was approximately 56\% (Table 11).

Table 11. Identification of two components of Customer Communication Complexity Index.

\begin{tabular}{ccccccc}
\hline \multirow{2}{*}{ Component } & \multicolumn{3}{c}{ Initial Values of Eigenvalues } & \multicolumn{2}{c}{ The Sum of Squares after Rotation } \\
\cline { 2 - 6 } & Total & \% Variance & \% Cumulated & Total & $\begin{array}{c}\text { Percent of } \\
\text { Variance }\end{array}$ & \% Cumulated \\
\hline 1 & 2.155 & 35.923 & 35.923 & 1.976 & 32.928 & 32.928 \\
2 & 1.212 & 20.204 & 56.127 & 1.392 & 23.199 & 56.127 \\
3 & 0.859 & 14.324 & 70.451 & & \\
4 & 0.773 & 12.882 & 83.333 & & \\
5 & 0.563 & 9.381 & 92.713 & & \\
6 & 0.437 & 7.287 & 100.000 & & \\
\hline
\end{tabular}

Assigning factors to CCCI components based on a matrix of rotational components (Table 12) enabled naming these components and giving them weight. They were normalized by sums of 
squares of charges that correspond to a part of the variance explained by a given component (Table 13). Constructed Customer Communication Complexity Index is shown as Equation (1):

$$
\mathrm{CCCI}=(0.587 \cdot \mathrm{C} 1) / 4+(0.413 \cdot \mathrm{C} 2) / 2=(0.514 \cdot(\mathrm{f} 1+\mathrm{f} 6+\mathrm{f} 7+\mathrm{f} 8)) / 4+(0.486 \cdot(\mathrm{f} 4+\mathrm{f} 5)) / 2 .
$$

Table 12. Matrix of rotated components for factors of the complexity of communication with customers.

\begin{tabular}{ccc}
\hline Factors & \multicolumn{2}{c}{ Components } \\
\cline { 2 - 3 } & C1 & C2 \\
\hline f1—traditional forms of promotion & 0.556 & 0.213 \\
f4-phone (traditional phone calls) & 0.003 & 0.856 \\
f5—email account & 0.194 & 0.777 \\
f6-corporate portals (personalized user accounts) & 0.536 & 0.053 \\
f7-external instant messaging & 0.816 & -0.004 \\
f8-social networks & 0.821 & 0.090
\end{tabular}

Method of extracting factors: principal components; rotation method: varimax with Kaiser's normalization. Rotation reached convergence in three iterations.

Table 13. Two main components of Customer Communication Complexity Index.

\begin{tabular}{ccccc}
\hline Component & Name of Component & $\begin{array}{c}\text { Scope of } \\
\text { Factors }\end{array}$ & $\begin{array}{c}\text { Defined Percent of } \\
\text { Variance after Rotation }\end{array}$ & $\begin{array}{c}\text { Weight for } \\
\text { CCCI }\end{array}$ \\
\hline $\mathrm{C} 1$ & $\begin{array}{c}\text { Simple, quick and traditional } \\
\text { forms of communication }\end{array}$ & $\mathrm{f} 1 ; \mathrm{f} 6-\mathrm{f} 8$ & 32.928 & 0.587 \\
\hline $\mathrm{C} 2$ & $\begin{array}{c}\text { Advanced and modern forms } \\
\text { of communication }\end{array}$ & $\mathrm{f} 4$ and f5 & 23.199 & 0.413 \\
\hline
\end{tabular}

The values of this indicator are described and interpreted below.

The next constructed indicator is the Customer Relationships Importance Index (CRII). For a full list of seven factors defining the impact of Customer Relations 4.0 on the development of the company, the Cronbach's alpha coefficient value was 0.789 - the first iteration (Table 14). The conducted analysis indicated that it is not possible to increase the reliability and quality of the scale in the case of removing further factors (Table 15). Descriptive statistics for factors used to construct CRII are included in Table 16.

The KMO coefficient for the CRII index assumed the value 0.648 , while the Bartlett's sphericity test showed that the hypothesis of uncorrelated coefficients can be rejected-the test statistic is 298,461 with the significance level lower than 0.001 . Therefore, further PCA analysis was justified and methodically correct (Table 17).

In the further analysis, the method of distinguishing main component factors with Varimax rotation was used-similar to CCCI. The selection of components was based on the Kaiser criterion. Factor analysis gave the basis for qualifying seven factors to two components whose sum of squares after rotation was approximately $67 \%$ (Table 18 ).

Table 14. Cronbach's alpha factor for factors of the importance of relationships with Customers 4.0 for the development of innovative enterprises.

\begin{tabular}{cc}
\hline Cronbach's Alpha & Number of Factors \\
\hline 0.789 & 7 \\
\hline
\end{tabular}


Table 15. Main factors of the importance of relationships with Customers 4.0-Cronbach's alpha statistics.

\begin{tabular}{cccc}
\hline Factors & $\begin{array}{c}\text { Mean of Scale after } \\
\text { Deleting Factor }\end{array}$ & $\begin{array}{c}\text { Variance of Scale after } \\
\text { Deleting Factor }\end{array}$ & $\begin{array}{c}\text { Cronbach's Alpha after } \\
\text { Deleting Factor }\end{array}$ \\
\hline $\begin{array}{c}\text { f1—implementation of } \\
\text { innovative processes }\end{array}$ & 25.6000 & 20.909 & 0.764 \\
f2—financial liquidity & 25.2900 & 21.299 & 0.754 \\
f3-market share & 25.8700 & 20.862 & 0.788 \\
f4—effectiveness and & 25.3500 & 20.896 & 0.742 \\
$\begin{array}{c}\text { continuity of basic processes } \\
\text { f5—-marketing processes }\end{array}$ & 25.8800 & 20.107 & 0.767 \\
f6—-minimizing the number & 25.2200 & 21.365 & 0.756 \\
$\quad$ of complaints & 25.2900 & 21.521 & 0.763 \\
f7-efficiency of core & & & \\
\hline business processes & & &
\end{tabular}

Table 16. Descriptive statistics for factors of the importance of relationships with Customers 4.0.

\begin{tabular}{ccc}
\hline Factors & Mean & Standard Deviation \\
\hline f1-implementation of innovative processes & 4.1500 & 1.15798 \\
f2—financial liquidity & 4.4600 & 1.00925 \\
f3—-market share & 3.8800 & 1.33545 \\
f4—effectiveness and continuity of basic processes & 4.4000 & 0.98473 \\
f5—-marketing processes & 3.8700 & 1.30000 \\
f6-minimizing the number of complaints & 4.5300 & 1.01956 \\
f7-efficiency of core business processes & 4.4600 & 1.04852 \\
\hline
\end{tabular}

Table 17. KMO sample adequacy and Bartlett test.

\begin{tabular}{ccc}
\hline & Statistics \\
\hline \multicolumn{2}{c}{ KMO sample adequacy } & 0.648 \\
\hline \multirow{3}{*}{ Bartlett test } & Approximate chi-square & 298.461 \\
& df & 21 \\
& Significance & 0.000 \\
\hline
\end{tabular}

Table 18. Identification of two components of Customer Relationships Importance Index.

\begin{tabular}{ccccccc}
\hline \multirow{2}{*}{ Component } & \multicolumn{3}{c}{ Initial Values of Eigenvalues } & \multicolumn{2}{c}{ The Sum of Squares after Rotation } \\
\cline { 2 - 6 } & Total & \% Variance & \% Cumulated & Total & \% Variance & \% Cumulated \\
\hline 1 & 3.204 & 45.768 & 45.768 & 2.401 & 34.303 & 34.303 \\
2 & 1.471 & 21.011 & 66.779 & 2.273 & 32.477 & 66.779 \\
3 & 0.901 & 12.869 & 79.648 & & & \\
4 & 0.622 & 8.890 & 88.538 & & \\
5 & 0.336 & 4.796 & 93.335 & & \\
6 & 0.299 & 4.275 & 97.610 & & \\
7 & 0.167 & 2.390 & 100.000 & & \\
\hline
\end{tabular}

Assigning factors to CRII components based on a rotating matrix (Table 19) made it possible to name these components and give them the weights (Table 20). Constructed Customer Relationships Importance Index is shown as Equation (2):

$$
\mathrm{CRII}=(0.514 \cdot \mathrm{C} 1) / 4+(0.486 \cdot \mathrm{C} 2) / 3=(0.514 \cdot(\mathrm{f} 1+\mathrm{f} 2+\mathrm{f} 3+\mathrm{f} 4)) / 4+(0.486 \cdot(\mathrm{f} 5+\mathrm{f} 6+\mathrm{f} 7)) / 3 .
$$

The values of the CCRI indicator will be described and interpreted later in the article. 
Table 19. Matrix of rotated components for factors of the importance of relationships with Customers 4.0 for the development of innovative enterprises.

\begin{tabular}{ccc}
\hline \multirow{2}{*}{ Factors } & \multicolumn{2}{c}{ Components } \\
\cline { 2 - 3 } & C1 & C2 \\
\hline f1-implementation of innovative processes in the enterprise & 0.865 & 0.017 \\
f2-financial liquidity & 0.721 & 0.306 \\
f3-market share & 0.664 & 0.055 \\
f4-effectiveness and continuity of basic processes & 0.792 & 0.297 \\
f5—-marketing processes & 0.179 & 0.750 \\
f6-minimizing the number of complaints & 0.108 & 0.920 \\
f7-efficiency of core business processes & 0.151 & 0.824
\end{tabular}

Method of extracting factors: principal components; rotation method: varimax with Kaiser's normalization. Rotation reached convergence in three iterations.

Table 20. Two main components of Customer Relationships Importance Index.

\begin{tabular}{ccccc}
\hline Component & Name of Component & $\begin{array}{c}\text { Scope of } \\
\text { Factors }\end{array}$ & $\begin{array}{c}\text { Defined Percent of } \\
\text { Variance after Rotation }\end{array}$ & $\begin{array}{c}\text { Weight for } \\
\text { CRII }\end{array}$ \\
\hline $\mathrm{C} 1$ & $\begin{array}{c}\text { Financial and market } \\
\text { (operational) security }\end{array}$ & $\mathrm{f} 1-\mathrm{f} 4$ & 34.303 & 0.514 \\
\hline $\mathrm{C} 2$ & $\begin{array}{c}\text { Relationships with the } \\
\text { environment }\end{array}$ & $\mathrm{f} 5-\mathrm{f} 7$ & 32.477 & 0.486 \\
\hline
\end{tabular}

\section{Analysis of Results}

The description of the obtained results should start with the analysis of the values of CCCI and CRII indicators. The distribution of CCCI values is characterized by weak left-side skewness-similarly for both components of this indicator (Figure 4). This means that the majority of the values of this indicator in the surveyed enterprises were higher than the average at 3.5584 (Table 21).

Taking into account the fact that each of the six factors included in the CCCI structure was assessed on a five-point scale, the average value of 3.5584 indicates that, on average, the complexity of communication with clients is high throughout the entire sample. The "limit" value (median) in the five-point scale is 3.00. In general, it can be assumed that the low level of communication complexity with clients is for CCCI values in the range $<1 ; 2.5$ ), average level in the range $<2,5,3.5$ ), and high in the range $\langle 3.5 ; 5>$. However, this is a contractual and standardized division, because a precise indication of the level of complexity of communication with customers requires the identification of the needs and capabilities of the company in this respect.
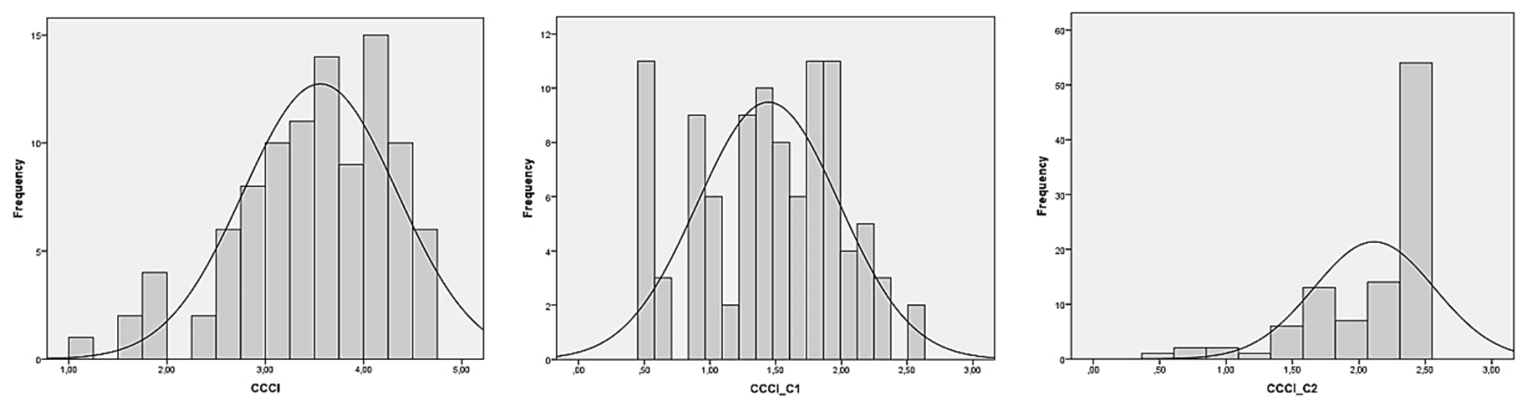

Figure 4. Distribution of values of CCCI, first component of CCCI, and second component of CCCI. 
Table 21. Descriptive statistics for CCCI two components of CCCI.

\begin{tabular}{cccc}
\hline & CCCI & CCCI_C1 & CCCI_C2 \\
\hline N & 100 & 100 & 100 \\
Mean & 3.5584 & 1.4443 & 2.1141 \\
Median & 3.7150 & 1.4778 & 2.4300 \\
Dominant & 4.36 & 0.51 & 2.43 \\
Standard deviation & 0.78292 & 0.54061 & 0.45363 \\
Variance & 0.613 & 0.292 & 0.206 \\
Skew & -0.636 & -0.183 & -1.576 \\
Kurtosis & 0.169 & -0.801 & 2.097 \\
Gap (maximum-minimum) & 3.76 & 2.06 & 1.94 \\
Minimum & 1.24 & 0.51 & 0.49 \\
Maximum & 5.00 & 2.57 & 2.43 \\
Sum & 355.84 & 144.43 & 211.41 \\
\hline
\end{tabular}

Knowing the average level of complexity of communication between enterprises and clients, it is possible to make an in-depth analysis of this issue from the perspective of particular areas of communication shaping (i.e., two components). For this purpose, the results of factor analysis were used, which provided the basis for grouping individual factors reflecting specific means of communication with clients into two thematically coherent components (Table 13). Since particular factors and CCCI components were evaluated on a five-point order scale, Friedman's test was used to assess the complexity of communication with customers and to construct a uniform ranking of components (Table 22). The lowest level of complexity of communication with clients in the surveyed enterprises concerned the area of simple, quick and traditional forms of communication (C1 component) - the result of the Friedman test with the average rank at 1.13. The largest complexity of communication with clients was noted for the $\mathrm{C} 2$ component, associated with advanced and modern forms of communication-the average rank at 1.87 (Table 23).

Table 22. Friedman's test-for two components of CCCI.

\begin{tabular}{cc}
\hline & Statistics \\
\hline $\mathrm{N}$ & 100 \\
Chi-square & 54.760 \\
$\mathrm{df}$ & 1 \\
Asymptotic significance & 0.000 \\
\hline
\end{tabular}

Table 23. Average ranks-for two components of CCCI.

\begin{tabular}{cc}
\hline & Average Ranks-For Each Component \\
\hline CCCI_C1 (simple, quick and traditional forms of communication) & 1.13 \\
CCCI_C2 (advanced and modern forms of communication) & 1.87 \\
\hline
\end{tabular}

A detailed list of six partial factors adopted in the study to construct the CCCI indicator and subjected to the Friedman test is presented in Tables 24 and 25. Respondents relatively often indicated that, in shaping the complexity of communication (in terms of establishing relationships) with clients, they consider traditional phone calls (average rank is 4.75) and email account (average rank is 4.47).

On the other hand, the surveyed enterprises were relatively least seen at social networks (average rank is 3.15) and traditional forms of promotion (average rank is 1.92). 
Table 24. Average ranks—-for each factor of CCCI.

\begin{tabular}{ccc}
\hline Factors & Average Ranks-For Each Factor & Mean \\
\hline f1-traditional forms of promotion & 1.92 & 1.7200 \\
f4-phone (traditional phone calls) & 4.75 & 4.5200 \\
f5—email account & 4.47 & 4.1800 \\
f6-corporate portals (personalized user accounts) & 3.24 & 3.2100 \\
f7- external instant messaging & 3.48 & 3.4000 \\
f8-social networks & 3.15 & 2.9100 \\
\hline
\end{tabular}

Table 25. Friedman's test-for each factor of CCCI.

\begin{tabular}{cc}
\hline & Statistics \\
\hline $\mathrm{N}$ & 100 \\
Chi-square & 192.829 \\
$\mathrm{df}$ & 5 \\
Asymptotic significance & 0.000 \\
\hline
\end{tabular}

Based on the above analysis it can be made a positive verification of Hypothesis 1 that says that the complexity of communication of innovative enterprises with customers is at a high level.

The distribution of CRII values is characterized by strong left-sided skewness-similarly in the case of both components of this indicator (Figure 5). This means that the vast majority of the value of this indicator in the surveyed enterprises was higher than the average at 4.2537 (Table 26). Taking into account the fact that each of the seven factors included in the CRII structure was assessed on a five-point scale, the average value at 4.2537 indicates that, on average, the impact of Customer Relationships 4.0 on the development of enterprises is high. The "limit" (median) value on a five-point scale is 3.00. Generally, it can be assumed that the low level of impact on enterprise development is for CRII values in the range $<1 ; 2.5)$, average level in the range $<2.5 ; 3.5)$, and high in the range $<3.5 ; 5>$. However, as for the CCCI indicator, this is a contractual division.
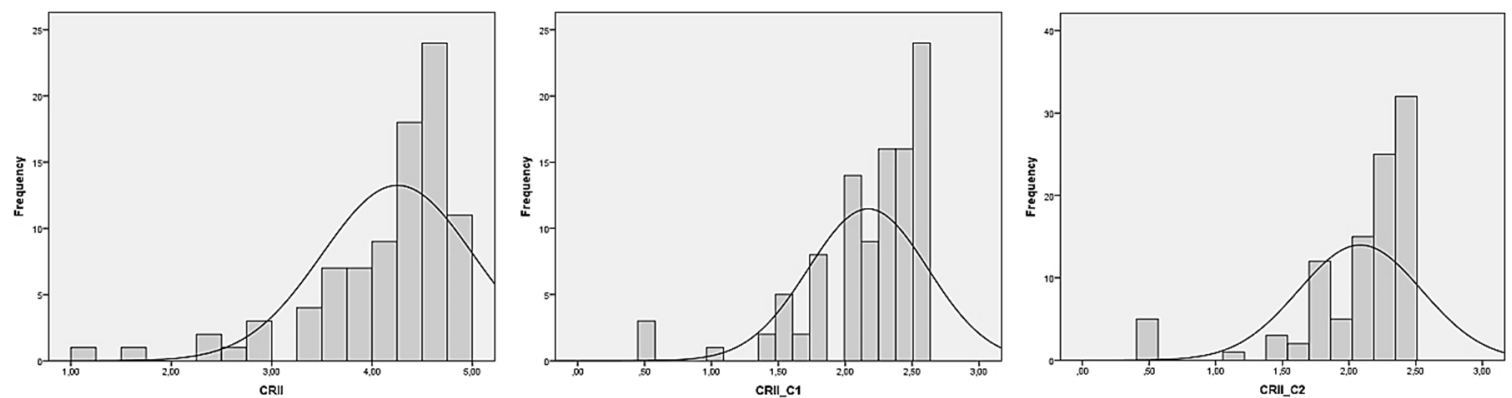

Figure 5. Distribution of values of CRII, first component of CRII, and second component of CRII.

Table 26. Descriptive statistics for CRII and two components of CRII.

\begin{tabular}{cccc}
\hline & CRII & CRII_C1 & CRII_C2 \\
\hline N & 100 & 100 & 100 \\
Gap (maximum-minimum) & 4.00 & 2.06 & 1.94 \\
Minimum & 1.00 & 0.51 & 0.49 \\
Maximum & 5.00 & 2.57 & 2.43 \\
Sum & 425.37 & 217.04 & 208.33 \\
Mean & 4.2537 & 2.1704 & 2.0833 \\
Standard deviation & 0.75281 & 0.44697 & 0.46225 \\
Variance & 0.567 & 0.200 & 0.214 \\
Skew & -1.873 & -1.849 & -2.193 \\
Kurtosis & 4.415 & 4.088 & 5.018 \\
\hline
\end{tabular}


Knowing the average level of impact of customer relations 4.0 on the development of the surveyed enterprises, it is possible to make an in-depth analysis of this issue from the perspective of particular areas of shaping this impact. For this purpose, the results of factor analysis were used, which provided the basis for grouping of individual factors reflecting specific areas of influence into two thematically coherent components (Table 20). Since individual factors and CRII components were assessed on a five-point order scale, the Friedman test was used to assess the significance of customer relationships 4.0 for the operations of enterprises and the construction of a uniform ranking of components (Table 27). The lowest level of impact of customer relations in the surveyed enterprises concerned the relationships with the environment (C2 component)—the Friedman test result with the average rank at 1.32. The largest impact of customer relationships was recorded for $\mathrm{C} 1$ component, related to financial and market (operational) security-average rank at 1.68 (Table 28).

Table 27. Friedman's test-for two components of CRII.

\begin{tabular}{cc}
\hline & Statistics \\
\hline $\mathrm{N}$ & 100 \\
Chi-square & 12.960 \\
$\mathrm{df}$ & 1 \\
Asymptotic significance & 0.000 \\
\hline
\end{tabular}

Table 28. Average ranks—-for two components of CRII.

\begin{tabular}{cc}
\hline & Average Ranks-For Each Component \\
\hline CRII_C1 (financial and market (operational) security) & 1.68 \\
CRII_C2 (relationships with the environment) & 1.32 \\
\hline
\end{tabular}

A detailed list of seven partial factors adopted in the study to construct the CRII index and those subjected to the Friedman test is presented in Tables 29 and 30. Respondents relatively often indicated that, in the shaping of enterprise development, the largest share is in the areas of minimizing the number of complaints (average rank is 4.59), financial liquidity (average rank is 4.42) and efficiency of core business processes (average rank is 4.40). On the other hand, the surveyed enterprises were relatively least seen at market share (average rank is 3.39) and marketing processes (average rank is 3.29).

Table 29. Average ranks—for each factor of CRII.

\begin{tabular}{ccc}
\hline Factors & Average Ranks-For Each Factor & Mean \\
\hline f1-implementation of innovative processes in the enterprise & 3.74 & 4.1500 \\
f2-financial liquidity & 4.42 & 4.4600 \\
f3-market share & 3.39 & 3.8800 \\
f4-effectiveness and continuity of basic processes & 4.19 & 4.4000 \\
f5-marketing processes & 3.29 & 3.8700 \\
f6-minimizing the number of complaints & 4.59 & 4.5300 \\
f7- efficiency of core business processes & 4.40 & 4.4600 \\
\hline
\end{tabular}

Table 30. Friedman's test-for each factor of CRII.

\begin{tabular}{cc}
\hline & Statistics \\
\hline $\mathrm{N}$ & 100 \\
Chi-square & 61.203 \\
$\mathrm{df}$ & 6 \\
Asymptotic significance & 0.000 \\
\hline
\end{tabular}


Based on the above analysis, it can be made a positive verification of Hypothesis 2 that says that the importance of relationships with Customers 4.0 for the development of innovative enterprises is at a high level.

Verification of Hypothesis 3 was carried out using non-parametric correlation (Spearman rho), because the CCCI and CRII ratios were not characterized by normal distribution (Table 31).

Table 31. Correlation between CCCI and CRII.

\begin{tabular}{|c|c|c|c|}
\hline & & & CRII \\
\hline \multirow{3}{*}{ rho Spearman } & & Correlation coefficient & 0.078 \\
\hline & CCCI & Significance (reversible) & 0.440 \\
\hline & & $\mathrm{N}$ & 100 \\
\hline
\end{tabular}

Based on the analysis of the Spearman rho coefficient (0.078), it can be assumed that there is a very weak positive correlation between the complexity of communication with clients and the impact of customer relations 4.0 on the development of the company. It should be noted, however, that this correlation is statistically insignificant. The correlation is statistically significant at 0.01 (reversible). Thus, Hypothesis 3, which indicates that the higher the level of complexity of relationships with Customers 4.0, the greater the importance of these relationships for the development of innovative enterprises can be negatively verified.

\section{Discussion}

Modern enterprises, especially those operating in innovative industries and sectors, should pay particular attention to shaping customer relations, including through the implementation of communication processes (e.g., marketing). This situation is gaining importance in conditions of dynamic development of Marketing 4.0, which is a kind of technological challenge for enterprises. Clients, as a result of a strong focus on the use of the most modern forms of Internet communication and the use of various ICT technologies, are in a sense a "challenge" for companies that are somewhat "forced" to meet the technological needs of customers (Saura and Bennett 2019). It is also important from the point of view of including Customers 4.0 in the processes of providing services or manufacturing products. Customers become an "integral part" of enterprises and their offerings, conditioning in a sense the "success" of their functioning on the market. That is why it is so important in the modern economy (based on ICT knowledge and technologies) to shape lasting and constructive relationships between enterprises and Clients 4.0. These relationships should be a source of value for both the company (affecting, for example, innovative processes) and the client.

It is worth emphasizing, however, that shaping relations with Customer 4.0 does not necessarily mean only engaging modern forms of communication. As demonstrated by empirical studies on the sample of innovative enterprises and Poland, the complexity of communication with Customer 4.0 may at the same time be of a high level and based on "traditional" and simple means of communication.

However, such a state of affairs does not necessarily mean that the importance of customer relations weakly or negatively affects the development of innovative enterprises and the fact that communication with Customer 4.0 is not important in the development of enterprises. Traditional methods of communication can also be "appreciated" by Customer 4.0 and should not be overlooked in contemporary business development conditions both in individual countries and on a global scale.

Thus, enterprises can effectively and efficiently shape their development through customer relations due to only (or mainly) the traditional communication, i.e., in the form of telephone and e-mail solutions. Social and corporate portals, instant messengers or mobile applications do not have to strongly and positively stimulate the development of innovative enterprises. An essential practical conclusion follows from the statement: excessive capital expenditures in the development of ICT infrastructure (in the field of communication with modern clients) are not always necessary and do not have to determine the development potential of enterprises and the effectiveness of innovative 
processes. Such investments can improve the image of the enterprise as a contemporary entity. However, this situation does not have to be synonymous with the multifaceted, business development of the enterprise.

It is also worth considering why modern means of communication with clients (including Customer 4.0) do not always have to be an effective source of the enterprise development. This may be due to, for example, from the need to allocate limited financial resources to business activities-greater expenditures for the development of the ICT technology area and communication with customers mean smaller investments in production or purchase. It should be remembered here that it is necessary to consider the alternative cost which in the case of shaping the development of innovative enterprises is of the crucial key. In addition, the rate of return on investment in the development of modern communication with clients can be low, and the payback period of such investments is very long. It should not be forgotten that an enterprise operating in the innovative industry must mean that every customer is "innovative" and requires the latest forms and means of communication. Even customers referred to as Customers 4.0, in many cases, may perceive the communication of using traditional carriers as more effective and efficient, for example in a situation where required standards/procedures are necessary for written forms of communication or the need to send specific documents/attachments as well confirmation/verification of the specific data (e.g., in the case of complaints or orders). Traditional means of communication are still perceived by customers as more "certain" and often more effective in having influence on the enterprise and "an interference" in the innovation processes.

\section{Conclusions}

The conducted research can be seen as a source of implications for the practice of innovative enterprises. It indicates how to shape the communication with clients, especially Customers 4.0 who actively and creatively participate in business operations of enterprises, including the participation in innovative processes and the co-creation of value. It is important in this case that innovative enterprises do not have to use many different modern ICT technologies and online means of communication with clients. Despite the fact that Customers 4.0 by definition are strongly oriented to the use of ICT, for example in purchasing processes, do not expect a large involvement in this area on the side of enterprises.

However, one should not go to extremes, i.e., "neglecting" investment in the development of ICT technologies in the processes of communication with clients. The recommended action is simply to identify the needs of clients (market segments) in this respect and the appropriate allocation of capital (investments). Only in such a situation the communication with clients (also Customers 4.0) can become a source of the development of innovative enterprises. Summing up, it can be seen that the above conclusions constitute the original input and value of the conducted research to the industry.

Concluding, from the practical point of view, each day brings new technological solutions which can be easily used by enterprises. However, from the research presented in the article, it can be noted that customers still need the face to face communication supported by ICT solutions as Internet and connected with it social media and/or different mobile applications. That is why the communication complexity system used by organizations in operating processes should be focused on the duality - traditional and modern forms of communication to sustain good relations with Customer 4.0, supporting new aspects of Marketing 4.0. The future research should be concentrated on the divisions of different forms of communication in acquiring information from enterprises by varied generations as customers because Generation Alpha has been growing in a different socioeconomic (more electronic) world than Generations Y and Z.

Author Contributions: Conceptualization, W.W.; Data curation, J.W.; Formal analysis, J.W.; Investigation, J.W.; Methodology, J.W.; Resources, W.W.; Supervision, W.W.; Visualization, W.W. and J.W.; and Writing一original draft, W.W.

Funding: This research received no external funding.

Conflicts of Interest: The authors declare no conflict of interest. 


\section{References}

Abedi, Vahideh Sadat. 2019. Compartmental diffusion modeling: Describing customer heterogeneity \& communication network to support decisions for new product introductions. Physica A. [CrossRef]

Amendola, Carlo, Mario Calabrese, and Francesco Caputo. 2018. Fashion companies and customer satisfaction: A relation mediated by Information and Communication Technologies. Journal of Retailing and Consumer Services 43: 251-57. [CrossRef]

Antonacci, Grazia, Andrea Fronzetti Colladon, Alessandro Stefanini, and Peter Gloor. 2017. It is rotating leaders who build the swarm: Social network determinants of growth for healthcare virtual communities of practice. Journal of Knowledge Management 21: 1218-39. [CrossRef]

Ayios, Angela, and Lisa Harris. 2005. Customer relationships in the e-economy: Mutual friends or just a veneering? Qualitative Market Research: An International Journal 8: 454-69. [CrossRef]

Bergman, Caroline, Lotta Dellve, and Katrin Skagert. 2016. Exploring communication processes in workplace meetings: A mixed methods study in a Swedish healthcare organization. Work 54: 533-41. [CrossRef] [PubMed]

Bowers, Keith, and Tina V. Pickerel. 2019. Vox Populi 4.0. Quality Progress 52: 32-39.

Calitz, Andre P., and Jaco F. Zietsman. 2018. An Adapted Framework for Environmental Sustainability Reporting using Mobile Technologies. African Journal of Information Systems 10: 174-90.

Caruso, Shirley J. 2018. Toward Understanding the Role of Web 2.0 Technology in Self-Directed Learning and Job Performance. Contemporary Issues in Education Research 11: 89-98. [CrossRef]

Claycomb, Cindy, and Charles L. Martin. 2001. Building customer relationships: An inventory of service providers' objectives and practices. Marketing Intelligence \& Planning 19: 385-99.

Contify Automotive News. 2018. 'Customer Service 4.0' at Rolls-Royce Power Systems-A New Service and Digital Strategy to Transform MTU's Global Customer Support. Available online: https://www.rrpowersystems.com/news/press-releases/press-detail/customer_service_40_at_rolls_royce_ power_systems_a_new_service_and_digital_strategy_to_transform_mtus_global_customer_support/ (accessed on 11 April 2019).

Cygler, Joanna. 2002. Strategic Alliances. Warsaw: Difin.

Czakon, Wojciech. 2012. Networks in Strategic Management. Warsaw: Wolters Kluwer Business.

Dahiya, Rekha, and Gayatri. 2018. A Research Paper on Digital Marketing Communication and Consumer Buying Decision Process: An Empirical Study in the Indian Passenger Car Market. Journal of Global Marketing 31: 73-95. [CrossRef]

Dalziel, Nurdilek, Fiona Harris, and Angus Laing. 2011. A multidimensional typology of customer relationships: from faltering to affective. International Journal of Bank Marketing 29: 398-432. [CrossRef]

Dejnaka, Agnieszka. 2013. Building a customer relationship. In Bible of E-Business. Edited by Dutko Maciej. Gliwice: Publishing House Helion.

Dimitrov, Kiril. 2016. Exploring the nuances in the relationship "culture-strategy" for the business world. Vanguard Scientific Instruments in Management Journal 13: 39.

Dombrowski, Uwe, Jonas Wullbrandt, and Simon Fochler. 2019. Center of Excellence for Lean Enterprise 4.0. Procedia Manufacturing 31: 66-71. [CrossRef]

Dukić, Branimir, Robert Obraz, and Stojanka Dukić. 2018. Possible applications of industry 4.0 based on customer relationship management in bakery. Technologica Acta 11: 17-24.

Engelbrecht, Adrian, Jin P. Gerlach, Alexander Benlian, and Peter Buxmann. 2019. How employees gain meta-knowledge using enterprise social networks: A validation and extension of communication visibility theory. The Journal of Strategic Information Systems. in press. [CrossRef]

Fastener. 2017. Dimac Servicing 4.0: Transforming Customer Interactions. American Fastener E Technologies Journal 33: 62-63.

Freeman, Roger Williams. 2017. Understanding Customer 4.0-The Customer Led Revolution. Available online: https://wcomc.org/2017May31-2 (accessed on 20 March 2019).

Grable, John E., and Angela C. Lyons. 2018. An Introduction to Big Data. Journal of Financial Service Professionals 72: $17-20$.

Green, Sarah. 2018. How will Industry 4.0 shape customer experience for borrowers? Mortgage Finance Gazette 149: 20 
Gregor, Bogdan. 2002. Evolution and modern concepts of marketing. Studia. Polska Akademia Nauk. Komitet Przestrzennego Zagospodarowania Kraju 112: 9-36.

Grover, Varun, Roger H. L. Chiang, Ting-Peng Liang, and Dongsong Zhang. 2018. Creating Strategic Business Value from Big Data Analytics: A Research Framework. Journal of Management Information Systems 35: 388-423. [CrossRef]

Gunasekaran, Angappa, Nachiappan Subramanian, and Eric Ngai. 2019. Quality management in the 21st century enterprises: Research pathway towards Industry 4.0. International Journal of Production Economics 207: 125-29. [CrossRef]

Hastings, Kathleen, and Chad Perry. 2000. Do services exporters build relationships? Some qualitative perspectives. Qualitative Market Research: An International Journal 3: 207-14. [CrossRef]

Heinonen, Kristina. 2014. Multiple perspectives on customer relationships. International Journal of Bank Marketing 32: 450-56. [CrossRef]

Herington, Carmel, and Scott Weaven. 2007. Can banks improve customer relationships with high quality online services? Managing Service Quality: An International Journal 17: 404-27. [CrossRef]

Hollman, Angela K., Sonja H. Bickford, and Janet L. Lear. 2018. Communication Processes of Information Technology Execu-tives in Higher Education. Journal of Organizational E End User Computing 30: 71-87.

Hudrliková, Lenka. 2013. Composite indicators as a useful tool for international comparison: The Europe 2020 example. Prague Economic Papers 4: 459-73. [CrossRef]

Isoraite, Margarita. 2016. Marketing Mix Theoretical Aspects. International Journal of Research-Granthaalayah 4: 25-37.

Jończyk, Joanna. 2010. Relations based on trust and improving the quality of public services. Wspótczesne Zarzadzanie 4: 139-48.

Kim, Taemie J., Maurice Chu, Oliver Brdiczka, and James Begole. 2009. Predicting shoppers' interest from social interactions using sociometric sensors. In CHI'09 Extended Abstracts on Human Factors in Computing Systems. New York: ACM, pp. 4513-18.

Kitchens, Brent, David Dobolyi, Jingjing Li, and Ahmed Abbasi. 2018. Advanced Customer Analytics: Strategic Value Through Integration of Relationship-Oriented Big Data. Journal of Management Information Systems 35: 540-74. [CrossRef]

Kotler, Philip. 1997. Marketing Mangement. Upper Saddle River: Practice Hall, New York: Practice Hall, pp. 12-13.

Kotler, Philip, Hermawan Kartajaya, and Iwan Setiawan. 2010. Marketing 4.0. From Products to Customers to Human Spirit. Hoboken: John Willey \& Sons, Inc., pp. 15-25.

Kotler, Philip, Hermawan Kartajaya, and Iwan Setiawan. 2017. Marketing 3.0. Moving from Traditional to Digital. Hoboken: John Willey \& Sons, Inc., pp. 13-20.

Kozłowski, Marek. 2012. Employer Branding-Building Step by Step the Image of the Employer. Warsaw: Wolter Kluwer Business.

Lee, Bo Youn, and So Young Park. 2019. The role of customer delight and customer equity for loyalty in upscale hotels. Journal of Hospitality and Tourism Management 39: 175-84. [CrossRef]

Lehrer, Christiane, Alexander Wieneke, Jan vom Brocke, Reinhard Jung, and Stefan Seidel. 2018. How Big Data Analytics Enables Service Innovation: Materiality, Affordance, and the Individualization of Service. Journal of Management Information Systems 35: 424-60. [CrossRef]

Lopes, Pedro. 2019. Report “Customer 4.0". Accenture Technology. Available online: http://aese.com.pt/ assembleia/files/Accenture_AESE.pdf (accessed on 15 February 2019).

Lorenz, Ruth, Kai Lorentzen, Nicole Stricker, and Gisela Lanza. 2018. Applying User Stories for a customer-driven Industry 4.0 Transformation. IFAC-PapersOnLine 51: 1335-40. [CrossRef]

Manufacturers. 2018. Industry 4.0 closes the gap between customer and supplier. Manufacturers' Monthly, November 14, p. 34.

Marston, Cam. 2005. Motivating the "What's In It For Me?" Workforce. Manage across the Generational Divide and Increase Profits. Hoboken: John Wiley.

Matinaro, Ville, Yang Liu, and Jurgen Poesche. 2019. Extracting key factors for sustainable development of enterprises: Case study of SMEs in Taiwan. Journal of Cleaner Production 209: 1152-69. [CrossRef]

Mourtzisa, D. Dimitris, Antonis Gargallis, and Vasilios Zogopoulos. 2019. Modelling of Customer Oriented Applications in Product Lifecycle using RAMI 4.0. Procedia Manufacturing 28: 31-36. [CrossRef] 
Müller, Oliver, Maria Fay, and Jan vom Brocke. 2018. The Effect of Big Data and Analytics on Firm Performance: An Econometric Analysis Considering Industry Characteristics. Journal of Management Information Systems 35: 488-509. [CrossRef]

Muzellec, Laurent, and Eamonn O'Raghallaigh. 2018. Mobile Technology and Its Impact On the Consumer Decision-Making Journey: How Brands Can Capture The Mobile-Driven “Ubiquitous” Moment of Truth Viewpoint. Journal of Advertising Research 58: 12-15. [CrossRef]

Nardo, Michela, Michaela Saisana, Andrea Saltelli, and Stefano Tarantola. 2005. Tools for Composite Indicators. Brussels: European Commission.

Nowacki, Filip. 2014. Marketing 4.0-A new concept in the face of modern consumer changes. Marketing i Rynek 6: 11-19.

OECD. 2008. Handbook on Constructing Composite Indicators. Methodology and User Guide. Brussels: OECD Publishing. Robbins, Stephen P. 2008. Organizational Behaviour. London: Pearson Prentice Hall.

Rostami, Ali, Amir Hossein Amir Khani, and Gholamali Soltani. 2016. The Impact of E-service Quality on the Improvement of the Level of Communication with Customers of Bank Melli Branches in South Tehran Affairs Office. Procedia Economics and Finance 36: 448-55. [CrossRef]

Rowley, Jennifer. 2005. Building brand webs: Customer relationship management through the Tesco Clubcard loyalty scheme. International Journal of Retail \& Distribution Management 33: 194-206.

Sajić, Mirko, Dušanka Bundalo, Zlatko Bundalo, and Dražen Pašalić. 2018. Using Digital and Mobile Technologies for Increasing Efficiency of Financial Institutions. Acta Technica Corvininesis-Bulletin of Engineering 11: $39-42$.

Samson, Rohan, Mita Mehta, and Arti Chandani. 2014. Impact of Online Digital Communication on Customer Buying Decision. Procedia Economics and Finance 11: 872-80. [CrossRef]

Saniuk, Sebastian, and Anna Saniuk. 2018. Challenges of Industry 4.0 for Production Enterprises Functioning Within Cyber Industry Networks. Management Systems in Production Engineering 26: 212-16. [CrossRef]

Saura, Jose Ramon, and Dag R. Bennett. 2019. A Three-Stage Methodological Process of Data Text Mining: A UGC Business Intelligence Analysis. Symmetry 11: 519. [CrossRef]

Saura, Jose Ramon, Pedro R. Palos-Sanchez, and Marisol B. Correia. 2019. Digital Marketing Strategies Based on the E-Business Model: Literature Review and Future Directions. In Organizational Transformation and Managing Innovation in the Fourth Industrial Revolution. Hershey: IGI Global.

Singh, Rajesh. 2003. Developing relationship marketing with customers: A Scandinavian perspective. Library Management 24: 34-43. [CrossRef]

Skaates, Maria, and Veikko Seppänen. 2005. Market-oriented resource management in customer relationships. Qualitative Market Research: An International Journal 8: 77-96. [CrossRef]

Stefanini, Alessandro, Davide Aloini, Elisabetta Benevento, Riccardo Dulmin, and Valeria Mininno. 2018. Performance analysis in emergency departments: A data-driven approach. Measuring Business Excellence 22: 130-45. [CrossRef]

Syreyshchikova, Nelli V., Danil Yu Pimenov, Tadeusz Mikolajczyk, and Liviu Moldovan. 2019. Information Safety Process Development According to ISO 27001 for an Industrial Enterprise. Procedia Manufacturing 32: 278-85. [CrossRef]

Tarabasz, Anna. 2013. The reevaluation of communication in customer approach-towards Marketing 4.0. International Journal of Contemporary Management 12: 124-34.

Todeva, Emanuela. 2006. Business Networks. Startegy and Structure. New York: Routledge.

Van den Berg, Martin, Raymond Slot, Marlies van Steenbergen, Peter Faasse, and Hans van Vliet. 2019. How enterprise architecture improves the quality of IT investment decisions. Journal of Systems and Software 152: 134-50. [CrossRef]

Verm, Nashi, and Sanman Jain Nellikar. 2018. Impact of knowledge management on organizations. International Journal of Advanced Research 6: 922-28. [CrossRef]

Wasserman, Stanley, and Katherine Faust. 1994. Social Network Analysis: Methods and Applications. New York: Cambridge University Press.

Weitz, Barton A. 1981. Effectiveness in Sales Interactions: A Contingency Framework. Journal of Marketing 45: 85-103. [CrossRef]

Wereda, Wioletta. 2012. Role of stakeholder orientation in management of organization sustainability. Hyperion Inter-national Journal of Econophysics and New Economy 5: 307-22. 
Wereda, Wioletta. 2018. Organization's agility towards developing the relationship sales model in the contemporary enterprise. Paper presented at the International Conference on Changes in Social and Business Environment CISABE 2018, Panevezys, Lithuania, April 26-27.

Wereda, Wioletta, and Piotr Zaskorski. 2018. Creating relationships with clients in the IT environment. In STRATEGICA. Challenging the Status Quo in Management and Economics, 1st ed. Edited by Constantin Brătianu, Alexandra Zbuchea and Alexandra Vitelar. Bucharest: Tritonic.

Williams, Brett, Andrys Onsman, and Ted Brown. 2012. Exploratory factor analysis: A five-step guide for novices. Australian Journal of Paramedicine 8: 1-13. [CrossRef]

Witek-Hajduk, Marzanna Katarzyna, Joanna Cygler, Andrzej Sznajder, Anna Napiórkowska, and Tomasz Napiórkowski. 2016. Relations between Producers and Retailers. The Context of Business Models. Warsaw: PWN.

Yashin, Tony. 1998. Integrated Marketing Communications. The Holistic Approach. Oxford: Butterworth Heinemann. Ziółkowska, Bogusława, and Karolina Karbownik. 2018. Modern information and communication technologies used in the tele-work management. Studies and Research of the FEM of the SU 52: 543-53.

(C) 2019 by the authors. Licensee MDPI, Basel, Switzerland. This article is an open access article distributed under the terms and conditions of the Creative Commons Attribution (CC BY) license (http://creativecommons.org/licenses/by/4.0/). 